\title{
EDUCATIONAL THEORY AS RHYTHMIC ACTION: FROM ARENDT TO AGAMBEN
}

\author{
N. Davids* \\ e-maill: nur@sun.ac.za
}

\author{
Y. Waghid* \\ yw@sun.ac.za \\ *Department of Education Policy Studies \\ Stellenbosch University \\ Stellenbosch, South Africa
}

\section{ABSTRACT}

Traditionally, educational theory has been couched as modes of human action through concepts such as poiesis and praxis. Inasmuch as poiesis and praxis have significantly shaped educational theory, we argue that such modes of action - if considered as mutually exclusive - do not sufficiently explain the interrelationship between educational theory and practice. Firstly, we extend the notion of action as explained by Arendt. Next, we offer an account of Agamben's 'opening of rhythm', which integrates the notions of poiesis and praxis to pave the way for an understanding of educational theory as creative will that moves human action from enacting the unexpected into 'an increasingly free and rarified atmosphere'. Secondly, in re-examining the Aristotelian concepts of poiesis and praxis, we argue that Agamben's 'opening of rhythm' extends the Arendtian notion of action to perform the unexpected, and offers an as yet unexplored lens through which to understand the nexus between educational theory and practice.

Keywords: poiesis, praxis, educational theory, practice, rhythmic action

\section{THEORISING EDUCATIONAL THEORY}

In this article we offer a defence of why educational theory should rightfully be considered as a mode of action. In doing so, we contest the misplaced dichotomy between educational theory and practice, and instead argue that a nexus exists between the two - meaning that not only is the one informed by the other, but that neither can exist without the other. When one acts, one does something - whether embarking upon something or engaging with someone. When one acts, one thinks; even when one thinks that one has acted without thinking (a thoughtless action), one thinks. The activities of producing (poiesis) and doing (praxis), embarking on or 
thinking can be couched as actions of a particular kind. So when one theorises one does something. In this way, one acts whether it is in the form of thinking, contemplating or (re)constructing meanings. That is, one brings into action what one has considered or thought. This action does not occur independently from what one thinks, or imagines, or contemplates. So, in a way, theory is inherent in practices. And as the theory improves, the practice might follow suit or become more enhanced, and, in turn, the practice might reinforce or alter the theory. Theory and practice, therefore, are never disconnected. To avoid theory is to become unmindful of what a practice actually is. That is, theory and practice are interrelated and constitute a nexus according to which they unfold as forms of human action.

As a backdrop to our argument in defence of educational theory as 'rhythmic' action, we draw on some contestations of the concept. Not only does theory have multiple meanings, which creates confusion, explains Thomas $(1997,75)$, but contemporary debate on methods of inquiry has concerned theory's fragility, not its utility. According to Carr (2006, 136), educational theory has been criticised for being nothing other than the name given to the various futile attempts to stand outside of educational practices in order to explain and justify them. And yet despite this fragility, says Thomas $(1997,76)$, the continuing resolve of educational theory can be ascribed to the absence of a community language system by which education academics and researchers understand theory; and drawing its epistemological legitimacy from the success of theory in other fields. The notion of theory as an intellectual endeavour is problematic in that it implies that any conjoining of words is a theoretical enterprise. To Thomas $(1997,79)$, the commonly held view that theory is simply the opposite of practice, constructing a theorypractice continuum, implies that theory is to be understood as speculation and book-learning. Rather, says Carr $(2006,140)$, not only is theory everything that practice is not, but educational theory is abstract rather than concrete, general rather than particular, context-free, rather than context-dependent.

Carr $(2006,146)$ maintains that while the existence of educational theory is acknowledged in relation to both educational research and the idea of practice, the apparent discomfort around educational theory is evident, on the one hand, in the view that although educational theory informs practice, educational theory is itself not a form of practice. On the other hand, says Thomas (1997, 76), educational theory is viewed as an instrument for reinforcing an existing set of practices and methods in education. If one considers the view that educational theory is nothing other than that which consolidates existing practices and methods in education, then it follows that educational theory offers something to practices and methods in education. This intimation already implies that practices and methods of education are somewhat impoverished 
if not guided by the notion of an educational theory. In this way, educational theory contributes towards making practices and methods of education what they are - that is, constituting and/or reinforcing other aspects of education. Put differently educational theory makes up or constitutes education without which the latter would not necessarily be able to be education. Similarly, the argument that educational theory is itself not a form of practice but informs teaching, is an acknowledgement that teaching cannot be teaching without being constituted by educational theory - that is, educational theory underscores teaching and hence becomes its (teaching) rationale or that which makes teaching what it is.

Our argument in defence of educational theory is premised on an understanding that education and some of its forms - whether, teaching, learning, or research practices and /or methods - cannot be, if unconstituted by educational theory. In a way, educational theory is that form of thinking (making or doing) - that is, practice or human action - which gives education its distinctive form. As such, education cannot be conceived of as motionless or unchanging, and it for this reason that we find Agamben (1999) appealing. Using Aristotle's (2004) conception of rhythm, and in drawing an analogy between art and a musical piece, Agamben describes how it is possible to perceive rhythm as 'something that escapes the incessant flight of instants and appears almost as the presence of an atemporal dimension in time. In the same way, when we are before a work of art or a landscape bathed in the light of its own presence, we perceive a stop in time, as though we were suddenly thrown into a more original time.' Agamben $(1999,58)$ explains that 'there is a stop, an interruption in the incessant flow of instants that, coming from the future, sinks into the past, and this interruption, this stop, is precisely what gives and reveals the particular status, the mode of presence proper to the work of art or the landscape we have before our eyes'. It is Agamben's depiction of an 'incessant flow of instances' that comes from the future and 'sinks into the past' - the sense of an 'opening of rhythm' - which, we will argue, offers a unique lens through which to understand the nexus between educational theory and practice.

\section{EDUCATIONAL THEORY AS DICHOTOMIZED AND LINKED MODES OF HUMAN ACTION}

Drawing on the seminal thoughts of MacIntyre and Arendt, respectively, the ensuing discussion will focus on how educational theory has been couched as modes of human actions through the concepts of poiesis (making) and praxis (doing). In a dialogue with Dunne, MacIntyre (2002, 5) contends that although each teacher is engaged in initiating her/his students into some practice - the use for which and the point of which the student cannot yet know - '[T]eaching 
itself is not a practice, but a set of skills and habits put to the service of a variety of practices'. For us such a MacIntyrean idea resonates with the notion of poiesis that is considered by Aristotle as producing say, a practice. In return, MacIntyre explains, the student can have one of two responses, s/he can either learn to care about 'getting it right', or learn to feel a sense of her own powers in getting it right. It is MacIntyre's (2002, 8-9) argument, that while teachers are involved in a variety of practices and that teaching is an ingredient in every practice, teaching is never more than a means - that is, an endeavour towards making something or poiesis. As such, he maintains, that teaching has no purpose beyond that of introducing students to the purpose of activities. All teaching is for the sake of something else and so teaching does not have its own goods.

The contention that teaching is never more than a means, and because it is for the sake of something else, does not have its own goods, is of course a contentious one. One can argue that teaching contributes to shaping the life worlds of students and in this way teaching produces a good that benefits students. Although the act of teaching is on forming the student, one would not yet know what might become of the student which does not justify discounting teaching as a means to an end as well. Nevertheless, what we deduce from MacIntyre's argument that teaching is a means only, is the assumption that there is something in poiesis that makes an educative practice, such as, teaching what it is. If teaching were just a means, then being so is inextricably dependent on that which makes teaching what it is. More specifically, the means of teaching (poiesis) constitutes teaching in a particular way which we refer to as its educational theory.

In acceding to Dunne's argument that the dialectic between the practice of teaching and the institution of the school is faithfully reflected in the case of teaching and school, MacIntyre $(2002,10)$ argues that what is important is to recognise that each (student) life is a single, if complex, narrative of a particular subject, someone whose life is a whole into which the different parts have to be integrated so that the pursuit of the goods of the home reinforces both the pursuit of the goods of the school, and the other diverse goods of a particular life. The particular mode of human action, then, that the student needs to embark on is constituted by an integration of that which is encountered in the private sphere (the goods of the home), the educational sphere (the school or university), as well as the social or world sphere, as encountered through a particular life and in others. The complexity of this integrated narrative is, of course, further complicated, or enhanced by the pursuit of integration in itself. Indeed, an integrated narrative might not necessarily be possible, or desirable, for that matter - leaving the student in conflict with the goods of the school or home, or both. Aware of this, MacIntyre 
(2002, 10) acknowledges that to integrate each life is not only a task, which might never be completed, but the task itself, is to understand those diverse goods as contributing to the ultimate good of the individual. This important type of understanding, he explains, is primarily practical rather than theoretical, and to acquire it is to see each individual human life as an answer to the question: 'What is the ultimate human good?'

It is reasonable, therefore, to infer that while the theoretical pursuit of the human good might in some sense hold a common understanding - meaning, that the pursuit of the human good must hold some connection, or some harmony with the pursuit of the social good - it would, however, be unreasonable to infer that the practical pursuit thereof would be equally harmonious, linear, or indeed, attainable. In expanding on MacIntyre, then, the pursuit of the human good might not be in the attainment of the pursuit, so that the pursuit reaches its objective, but rather that the attainment thereof is in the pursuit itself, since the ultimate good is in fact, one of always being in pursuit. Inasmuch as MacIntyre himself attributes the reason for the ongoing pursuit to practices themselves, such practices can unfold only as a consequence of the reasons that make them justifiable pursuits. And, this is what we refer to as educational theory - those reasons that make the pursuit of practices possible and without which practices would not be in existence. In a different way, the practices of teaching in a MacIntyrean sense are enacted according to reasons or means which underscore the enactment of such practices a matter of poiesis (means) of making the actions what they are or can yet become. Thus, whereas it seems as if MacIntyre dichotomizes poiesis and praxis, our understanding is that such a bifurcation is not plausible. Hence, we move on to a discussion of the interconnectedness between making and doing, more specifically theory and practice.

\section{EDUCATIONAL THEORY AS LINKED MODES OF HUMAN ACTION}

In asserting that 'Men are conditioned beings because everything they come into contact with turns immediately into a condition of their existence', Arendt $(1958,9)$ draws a distinction between vita activa (active life) and vita contemplativa (contemplative life). The vita activa is '[A]lways rooted in a world of men and of manmade things which it never leaves or altogether transcends ... All human activities are conditioned by the fact that men live together, but it is only action that cannot even be imagined outside the society of men' (Arendt 1958, 22). Based on this explication of vita activa, she identifies three autonomous activities - labour, work and action - within four possible domains: the political, the social, the public, and the private. Yet, even in offering the two visions of vita activa and vita contemplativa, it is not Arendt's (1958, 14) intention to divert or juxtapose the two. In its reflections and deliberations on that which 
might exist outside the social and political - that is, a form of transcendence - vita contemplativa is seen by Arendt as 'as the only truly free way of life'.

Through vita activa - labour, work and action, that is, praxis - it is possible, says Arendt, to encounter a particular way of being, which is other than what we have thus far encountered, by the simple virtue of humanity. As Aristotle's 'rational animals', it is possible for humans to assume particular forms of existences, to construct new meanings, new ways of being, which will make them better, and able to achieve more, because, according to Arendt $(1958,9)$, 'Whatever touches or enters into a sustained relationship with human life immediately assumes the character of a condition of human existence'. To Arendt, human existence is signified as human due to the fact of plurality - meaning that each human being is unique and at the same time equal with all other human beings by sharing this precondition. In this sense, Lenz (2011, 17) explains that Arendt regards human existence as crucially political, which, for her, means being capable of taking part in the construction of the modes and conditions of living together. Arendt $(1958,175)$ argues that 'Human plurality, the basic condition of both action and speech, has the twofold character of equality and distinction. If men were not equal, they could neither understand each other and those who came before them nor plan for the future and foresee the needs of those who will come after them.' This plurality, says Lenz $(2011,17)$, results in the capacity and the need to create a common realm of existence, or in Arendt's terms - 'world' as the space which emerges from human action and interaction.

To Arendt, education creates the medium and space for individuals to come together so that they might reach their individual potential by actively engaging with each other. By participating and engaging with the other, they bring their individual pasts to a collective 'world' - which allows them to engage with the 'world' - thereby ensuring that the 'world' is sustained. Education, for Arendt, has the function of enabling human beings, especially the 'newcomers' in the chains of generations, to actively participate in the maintenance and continuance of 'world' and thereby realise their human potential. As such, clarifies Lenz (2011, 17), it is possible to imagine education as a process integrating all members of a society in the constant construction, reconstruction and maintenance of social, political and cultural life.

For us, the fascination of Arendt's $(1958,178)$ argument is in her emphasis on action as central to human existence in order that people perform the unexpected, the 'infinitely improbable'. This means that human action is boundless, uncertain of its outcome, and everrecurring. Through coming into contact, the human existence, says Arendt, is able to assume whatever condition it desires. As such, humans are able to construct new understandings, and new ways of being, because their condition is only made visible through acting, working and 
doing with others. What this means is that the human condition is not only undetermined and undecided, but it is always in a state of becoming. When teachers, then, do the work of teaching, they need both the theory of education and the practice of teaching to do so. Similarly, when students learn, they need the theory, and the practical application thereof in order to demonstrate that they have indeed learnt. The student shows that (s)he can solve for $\mathrm{x}$ as evidence that (s)he has understood and is therefore able to realise and apply what (s)he has learnt. The work of teaching and learning, therefore, involves both theory and practice. And because of its indeterminacy and endless possibility, it remains in a perpetual state of becoming and unfinality. Thus, whereas poiesis is concerned with the reasons for acting, praxis with the culmination of the reasons into critical action, vita activa - as a combination of poiesis and praxis - is concerned with action towards the unexpected, that is, what is yet to come. Through vita activa humans show a constant willingness to engage, and change their minds to start anew (Arendt 1958, 240).

Thus far we have shown how the philosophical conceptions of poiesis and praxis, informed by active life, always invoke both theory as contemplative action, and doing as emancipatory and undeterminable action - that is, through being mindful of the end purposes of interpretation (poiesis), emancipation and becoming (praxis). By extending the aforementioned integrated view, we will next turn our attention to Agamben's (1999) radical Aristotelian conception of rhythm. The two concepts, poiesis and praxis, cannot be separated and that such a nexus has a better chance of being realised if explored through Agamben's notion of an 'opening of rhythm'. In his integration of the concepts, poiesis and praxis, the distinctiveness of Agamben's 'opening of rhythm' paves the way for an understanding of educational theory as creative will that moves people into 'an increasingly free and rarified atmosphere' beyond just doing the unexpected, the improbable as Arendt contends. To us, merely looking at MacIntyre and Arendt, does not offer us enough in advancing our argument of a theory-practice nexus. While Arendt's explication of human existence being able to assume whatever condition it desires, takes us towards the unexpected, it does not shift beyond a linear exploration of poiesis and praxis - that is moving linearly in some direction from a means to an ends, or vice versa. What we now wish to do is to argue that the movement towards producing and doing cannot just be some sort of linear progression, as such an understanding would discount the view that things happen unexpectedly and haphazardly. It is for this reason that we offer an account of a non-linear understanding of the relationship between theory and practice - an understanding that lends itself to rhythmic action. Arendt's $(1958,246)$ aversion to doing things along 'a path secured in all directions' is noted as being self-defeating in the pursuit of 
conducting human affairs. She is quick to caution against the use of mutual and linear thinking as enormously risky for starting anew. It is the latter view that we hope to extend on the basis that unexpected new beginnings cannot exclusively rely on mutuality and linear progression, but rather, on rhythmic action. For an expansion of this idea, we now turn to a discussion of the work of Giorgio Agamben.

\section{EDUCATIONAL THEORY AS RHYTHMIC MODES OF HUMAN ACTION}

Praxis, explains Agamben (1999), has been understood as the idea of the will that finds its immediate expression in an act. By contrast, poiesis is the experience of pro-duction into presence - meaning, that something passed from non-being to being, from concealment into the full light of the work. Stated differently, says Lewis (2011, 249), while praxis has become the active intervention of a subject imbued with a god-like Will to Power (thereby dominating the world), poiesis is a pro-duction of a world for human action. Yet, states Agamben (1999, 42), the status of a man's dwelling on earth is a practical one, because of his productive status - the essential character of poiesis 'was not its aspect as a practical and voluntary process but its being a mode of truth understood as unveiling'. Agamben $(1999,68)$ explains that according to Aristotle, the roots of praxis are found in the very condition of man as an animal - that is, a living being, who is constituted by the very principle of motion that characterizes life - 'all of man's doing - that of the artist and the craftsman as well as that of the workman and the politician - is praxis, that is, a manifestation of a will that produces a concrete effect'. In this sense, motion, according to Agamben $(1999,43)$, is to be understood as the human will in terms of desire, volition and craving - conceived by Aristotle as will, drive, and vital impulse. Continuing, Agamben $(1999,43)$ contends, 'For while poiesis constructs the space where man finds his certitude and where he ensures the freedom and duration of his action, the presupposition of work is, on the contrary, bare biological existence, the cyclical processes of the human body, whose metabolism and whose energy depend on the basic products of labor'.

To Agamben $(1999,44)$, the notion of work (doing) is so intimately tied to the biological cycle of humans, that any attempts to argue differently have always returned to an interpretation of life, of man as a living being in which the philosophy of man's 'doing' continues to be a philosophy of life. He explains that everything is rhythm: the entire destiny of man is one heavenly rhythm, just as every work of art is one rhythm. Agamben maintains that rhythm is the structure of poiesis, which is a particular form of pro-duction distinct from praxis (Lewis 2011, 249). Rhythm, says Agamben, is not structure, but is instead the principle of presence that opens and maintains the work of art in its original space. Paradoxically, he explains, it is 
neither calculable nor rational; yet it is also not irrational. The essence of rhythm, he continues, is to flow, as in the case of water, or a musical piece - which flows, and then stops. As such, says Agamben (1999, 58-62), '[w]e perceive rhythm as something that escapes the incessant flight of instants and appears almost as the presence of an atemporal dimension in time'.

In his analogy between music and art, Agamben states that rhythm is something that escapes an 'incessant flight of instance'. If something does not appear incessantly, and instantaneously, it actually appears rhythmically, in other words - there is a moment of holding and giving back - as one might listen and be moved by the crescendos of music. Agamben's argument is that in the same way that we listen to music, we look at art, where we experience a suspension in time in which you reflect on the painting and re-depict the image as the painting reveals itself. In Agamben $(1999,62)$ fashion, beholding a work of art is not a static action, but rather ecstatic - 'It means ecstasy in the epochal in the opening of rhythm which gives and holds back ...'. What we infer from Agamben's use of the notion of rhythm in relation to educational theory and practice are two things: First, rhythm converges poiesis (making /production) and doing; and, second, rhythm signifies an elastic movement of giving and holding back. In light of these two aspects, if we look at the nexus between theory and practice as the opening of rhythm then momentarily one can think, or hold back one's thoughts as one embarks on a practice of making meaning of what encounters, and of the world. It might be that at times the theory will be more pronounced than the practice, and other times the practice might be more accentuated than the theory without the nexus being dismantled. For example, if the relationship between a supervisor and a doctoral student is open to rhythm, then there is already an acknowledgement that the work will have both a theoretical and practical orientation - a convergence - on the basis that the educational experience is not averse to the theory-practice nexus. So, at times, theoretical discussions might foreground discussion as the practice of theorising in relation to literature and human action are pursued. Other times, and perhaps concurrently, the student's practical bias to the project might hold sway and she envisages that the practice informs the theory. In other words, there appears to be a harmonisation between a practical element of the thesis and its (in)commensurability with the theoretical ideas that are articulated in the thesis. To this end, a rhythmic nexus between theory and practice addresses the often pseudo separation between theory and practice.

Unlike Arendt (1958) who considers action as a manifestation of the act of making into the act of doing and vice versa, Agamben (1999) views action as making (poiesis) and doing (praxis) rhythmically - that is, the potentiality of making and doing is always there as long as such acts are pursued concomitantly and in resonance with sporadic moments of interruption 
(holding back and opening up simultaneously). For example, teaching can at once be an act of withholding speech on the part of educators who provoke students to 'come to speech' by themselves and, they (educators) articulating speech as an opening up of their lived experiences as they endeavour to evoke the potentialities of their students. In short, teaching becomes both provoking and evoking speech - that is, making and producing ruptured rhythmic action as opposed to smooth and unstriated action. Lewis (2011, 251) clarifies that through negating any notion of linear chronology unfolding, the rhythm of poiesis is simultaneously projective and recursive. Smooth action limits possibilities towards the improbable, whereas unstriated action deters the possibility towards unexpected ruptures in thought and action in the same way a teacher transmits information to passive recipients who dare not question unbridled pedagogical authority. Put differently, rhythmic action engenders opportunities for teachers to question and be questioned simultaneously and, to rupture and be ruptured - a matter of stimulating students to learn through speech and coming to speech. Any action that is accompanied by rhythm has a potentiality to produce an alteration within others - a matter of producing change within people and texts. Students subjected to an opening of rhythm are summoned to speech by educators - that is, they are invited to come to their own conclusions and justifications and in turn, evolve into altered others with perhaps more informed views than what they previously had. Similarly, rhythmic action engenders opportunities for altering theories and practices along the lines of coming interruptions. That is, sometimes theories can be justifiably interrupted to alter practices and equally practices can be modified to give rise to more credible theories. The point we are making, is that rhythmic action not only enhances the interplay or convergence between theory and practices, but also sporadically interrupts the interplay to engender interruptions that are striated and inconclusive.

In sum, rhythmic action appropriately explains the nexus of educational theory and practice. Such a nexus is plausible in the sense that educational theory and practice invariably inform and consolidate one another. In turn the nexus of theory and practice rebuts linear, ordered and foundational action and in turn produces (poiesis) and enacts (praxis) action that is chaotic and unconstrained. Hence, such a nexus of educational theory and practice is rhythmic as it disrupts the possibility that human action should ever be linear and pre-empted. Such action would be remiss of the unexpected possibilities educative relations might engender for those who engage in such action.

\section{TOWARDS A CONCLUSION: RHYTHMIC ACTION AS A REVERSAL OF HUMAN ACTION}

Thus far, in Agamben fashion we have argued for a convergence between poiesis and praxis. 
Like Agamben we contend that all forms of human action should be interpreted as making (poiesis) and doing (praxis). In other words, it is implausible to think of making and doing as exclusive modes of human action. Rather, poiesis and praxis are convergent human actions held together by being open to rhythm. In a way, humans live themselves out productively and creatively in work. When such human action is reversed, it immediately sets into motion an interruption that reverses the action - that is, in / through interruption, human action is (re)produced. This push and pull towards and from an educative activity like teaching, learning and managing spawns rhythmic action: Human action manifests in an educative activity and simultaneously in an educative activity human action produces itself. This renewed status of human action being produced in educative relations - as activities depend on relationships not only blurs the distinction between poiesis and praxis but also gives action a theoreticalcum-practical impetus. In other words, action brings itself into the presence of educative relations. It is this bringing of the self into presence that Agamben $(1999,75)$ in Aristotelian fashion connects with willing action. That is, a human being 'wills his [her] action and, willing it, goes through to its limit'. Moreover, willing action is also linked to rhythm, 'to flow, as in the case of water ... [it] introduces into this eternal flow a split and stop ... something that escapes the incessant flight of instants and appears almost as the presence of an atemporal dimension' (Agamben 1999, 99). So, rhythmic action is associated with an interruption or stop that reveals the presence of the human will to the educative activity before our eyes. Put differently, rhythm holds back or suspends and simultaneously offers or hands over to the present. According to Agamben (1999, 101), rhythm gives humans their presence in the world in which they willingly pursue their activities such as freedom, alienation, truth and error.

Now if we further analyse education in terms of rhythmic action it implies that those who engage in such a human activity (education, after all, is in the Aristotelian sense a form of social action) engage wilfully and hand themselves over to the present - albeit presence of others and offer their judgements and/or understandings of themselves and the world to others. Concurrently they willingly suspend or hold back any misunderstandings or misjudgements as truths become more pronounced in the face of obvious mistakes being made. This rhythmic process of human engagement is constantly produced and reproduced through interruptions that cause people to remain in one another's presence. Humans risk to be provoked and interrogated by one another and wilfully suspend irrational flaws as they poetically (making action) and praxically (pruding action) (re)construct more defensible reasons in the presence of others. To us, Agamben's use of an Aristotelian conception of rhythm allows us to explain and understand education not only as a reiterative backward and forward motion, but as an interruption, 
suspension and resumption of human action, in which we collapse poiesis and praxis as two inseparable human acts. Such a form of education - which interrupts, suspends and resumes would enhance the capability of humans to offer themselves in the presence of others. Hopefully, such a rhythmic view of education and its concomitant relations amongst humans will harness their (humans') potential towards free, new and unending processes of becoming that, in the words of Arendt (1958, 241), 'could go on endlessly'. Put differently, whereas Arendt and Agamben seem to have in mind autonomous and emancipatory educative relations, it is the notion of rhythmic action that offers more promise to cultivate unexpected, and new rebeginnings.

This brings us finally to an Agambenian notion of action that integrates poiesis and praxis in the quest to foster rhythmic re-beginnings, more specifically educative relations. Whereas, an Arendtian notion of action implores humans to be attentive to forgiving and promising in starting anew, Agamben's idea of rhythm pulls and pushes them (humans) towards and away from such standard moral concepts. For Arendt (1958, 245), new beginnings are only possible if humans are ready to forgive and make promises not to jeopardise their future relations. However, at times, it seems inconceivable that the unforgivable, such as the holocaust, will be ever forgiven - a condition that might curtail real reconciliation. Following Agamben's idea of being open to rhythm, it implies that sometimes acts of horror and genocide like the holocaust can be forgiven and other times not. Hence, Agamben $(2002,69)$ is reluctant to encourage recourse to such moral concepts like forgiveness, promise, dignity and respect:

... Auschwitz marks the end and the ruin of every ethics of dignity and conformity to a norm ... The good that the survivors were able to save from the camp - if there is any sense in speaking of 'good' here - is therefore not dignity. On the contrary, the atrocious news that the survivors carry from the camp to the land of human beings is precisely that it is possible to lose dignity and decency beyond imagination, that there is still life in the most extreme of degradation ... But this proximity to death may also have another, more appalling meaning, one which concerns the dignity or indignity of death rather than life.

Only when humans pushed themselves towards indignity such as what the survivors of the holocaust encountered - for example, having exposed themselves shamefully in nudity - and, then pulled away from it - in readiness to be tortured and murdered - could thy have been ready for a new form of life based on recognition of rights and justice. In other words, if humans recognise the potentiality in them to act both humanely and inhumanely through pulling themselves away from what they are pushed towards, then the possibility is always there for perhaps more humane interrelationships. In short, to think about something beneficial (poiesis) in the quest to cultivate goodness (praxis) would go some way to attain the humanity within a world so often confronted with inhumanity. 


\section{REFERENCES}

Agamben, G. 1999. The man without content. Trans. Georgia Albert. Stanford: Stanford University Press.

Agamben, G. 2002. Remnants of Auschwitz: The witness and the archive. Trans. D Heller-Roazen. Cambridge, Massachusetts: The MIT Press.

Arendt, H. 1958. The human condition. $2^{\text {nd }}$ Edition. Chicago: The University of Chicago Press.

Aristotle, 2004. The Nicomachean ethics. Trans. J. A. K. Thomson. London: Penguin Books.

Carr, W. 2006. Education without theory. British Journal of Educational Studies 54(2): 136-159.

Lenz, C. 2011. The key role of education for sustainable democratic societies. In Teacher education for change: The theory behind the council of Europe Pestalozzi Program, ed. J. Huber and P. Mompoint-Gaillard. Strasbourg-Cedex: Council of Europe Publishing.

Lewis, T. E. 2011. The poetics of learning: Whitehead and Agamben on Rhythm. Philosophy of Education: 249-256.

MacIntyre, A. C. and J. Dunne. 2002. Alasdair MacIntyre on education: In dialogue with Joseph Dunne. Journal of Philosophy of Education 36(1): 1-19.

Thomas, G. 1997. What's the use of theory? Harvard Educational Review 67(1): 75-104. 